\title{
Change-Management is Still Prolific Subject to Business Management: A Biblio-Profile from 2019- 2000
}

\author{
Zameer Hussain Baladi, Saleh Ali Al-Qarni*
}

King Saud Bin Abdulaziz University for Health Sciences, College of Applied Medical Sciences, Riyadh, Kingdom of Saudi Arabia

DOI: $10.36347 /$ sjebm.2020.v07i10.003

| Received: 08.10.2020 | Accepted: 26.10.2020 | Published: 30.10 .2020

*Corresponding author: Saleh Ali Al-Qarni

Abstract

Original Research Article

\begin{abstract}
Aim of the research: This is a retrospective and theoretical study to evaluate the productivity of change-management aspects of a subject to the business community through the literature produced and published in journals enlisted to the Scopus-Elsevier database from 2000-2019. Methods/Approach: The study material downloads in coma-separated value (CSV) with note-paid files and to store and tabulated in MS Excel for examination. There were six objectives set to examine: Quantity and types of publications, the language of documents, total participation and affiliation of authors with their countries, top-cited records, and classification of the published data of documents set as objectives. Results: Total 1721 documents downloaded to investigate, 1686 forms existing on 11 academic formats, covers six disciplines, written in twelve languages by 4311 authors affiliated with 86 countries included to examine the subjects reflect as a change-management from 2019-2000. Conclusion: This study reflects that the sensitivity of the discipline of change-management took importance in the academic world situated in the developed world to underdeveloped countries to change the business scenario.

Keywords: Bibliometric, change-management, management, business, workplace.

Copyright (C) 2020 The Author(s): This is an open-access article distributed under the terms of the Creative Commons Attribution 4.0 International License (CC BY-NC 4.0) which permits unrestricted use, distribution, and reproduction in any medium for non-commercial use provided the original author and source are credited.
\end{abstract}

\section{INTRODUCTION AND LITERATURE REVIEW}

The word change-management affected people working with and in any organization in every capacity. It is not a word, but this is a process of changes; changes in the terminology of work, changes in strategies to get results, changes in the financial methodologies, changes in stages to evaluate the project implementations, changes in the environmental psychologies of the human resources, and changes in the approaches and definitions of business analysis.

An exciting study designed to explore change management's effectiveness on professional employees' attitudes toward the libraries, museums, and archival institutions of Croatia by Dukic, G [1]. The study received 242 employees' responses and found that after occurring the change in management, they felt a mildly positive attitude to perceive success. Callinan, M [2] introduced a suitable model to evaluate the process of operating efficiency, knowledge management and its transfer, mode of communications, perception, and culture of an organization, and over-look the matters affiliated with risk management under the name of an environment system.
Hajri, I et al., [3] focus on the product line modeling, which industrial management requires approaching product-specific development and testing in lines for use case-driven. This model methods support in variability, diagrams, and specifically in avoiding unnecessary traceability of other models. Alsanad, A., Chikh, A [4] agreed on the problems faced by the development sector in the name of change, and they further assure that dealing with this problem is not easy to avoid threats, which ultimately reduced the speed of success. Additionally, they proposed a comprehensive information technology-based model with a logical structure to get results accurately, efficiently, and quickly. Alqahtani, AA, et al., [5] execute a qualitative survey in Kuwait's public schools to identify the concerns and factors of influences in organizations. Through the using of multi-sequential design, the result reveals that two broad terms; effective leadership and conflict management comes to the surface among group discussions.

In 2017, Al-Ali, AA et al., [6] surveyed 210 public sector firms of the United Arab Emirates (UAE) to explore the impact of change management and leadership among the middle management respondents in organizational culture. The study finds that the 
change-oriented administration in the hierarchy has a significant effect on an organization's insight. Victoria, GM et al., [7] paid focuses on delivering and implementing healthcare management information systems in primary healthcare centers. They realized that change-management strategies designed and timely approach is more difficult to transform for success. Yeole, A., Kalbande, D.R [8] agreed with Victoria, G. M., and suggested to adopt internet of things technologies to transmit process gradually in the transmission of resources through the mode of operations.

Sulistiyani, E., Susanto, T.D [9] backed the arguments of failure and success of the practice and usage of information technologies to implement change management in the business's healthcare system. They provide a long list of steps in the identification of electronic characteristics imposed by authorities. Gupta, $S$ [10], optimistic about the manufacturing industry's methodologies in the name of change-management to compete for the criteria and grow their businesses in a protective market. Bonanomi, M.M. [11] reached to step further and proposed applied process and implementations of change-management methodologies as a case study in a multidisciplinary firm to identify the changes model of assessing and visualization in organizational structure.

Potdar, A., Unnikrishnan, S., Singh, A [12] surveyed 166 Indian business organizations to know the mitigation framework on climate change management. Procurement badly affected by climate as a risk in supply chain management due to the related standards and rules, which required further consultation. Nuraliati, A et al., [13] also provide the evidence with their explanatory research through a questionnaire that; how change-managements affect quality management both positively and negatively. Svarre Kristensen, $\mathrm{N}$ et al., [14] present a paper on balancing organizational change management process to create and change curriculum structure-based on action research in a new concept for facilitation and collaboration among faculty members in semester education. Kho, J et al., [15] focused on providing change-management in telemedicine services, which enable them to get advice on diagnosis and treatments remotely. They applied for systemic review in the bibliographic databases of Web of Sciences, PubMed, and CINHAL from 2008 - 2019. Research finds that 16 articles are relevant to changemanagement strategic and operational aspects from 48 articles, which were downloaded and selected to examine.

\section{METHODS/APPROACH}

The study's data explored in journals enlisted to the Scopus-Elsevier database, download in comaseparated value (CSV) with note-paid file to store, and tabulated in MS Excel for examination. There were six objectives set to examine:

- Quantity and types of publications

- The language of documents

- Total participation and affiliation of authors with their countries

- Top-cited records

- Classification of the published data of documents set as objectives

\section{RESULTS}

Table-1 shows that total 1721 documents downloaded to evaluate and after examination, 1686 documents were set to investigate. Total 1686 documents written by $4311 ; 2.5 \%$ authors from 2000 2019.

Table-1: Documents downloaded for study on the subject change-management from $2000-2019$

\begin{tabular}{|l|l|l|l|l|l|}
\hline S.No & Years & Documents download & Documents excluded & $\begin{array}{l}\text { Documents included to } \\
\text { investigate }\end{array}$ & Total authors participates \\
\hline 1 & Year 2019 & 133 & 3 & 130 & 408 \\
\hline 2 & Year 2018 & 99 & 0 & 99 & 288 \\
\hline 3 & Year 2017 & 142 & 2 & 140 & 342 \\
\hline 4 & Year 2016 & 120 & 3 & 117 & 310 \\
\hline 5 & Year 2015 & 118 & 2 & 116 & 304 \\
\hline 6 & Year 2014 & 91 & 3 & 88 & 207 \\
\hline 7 & Year 2013 & 114 & 3 & 111 & 296 \\
\hline 8 & Year 2012 & 109 & 2 & 107 & 277 \\
\hline 9 & Year 2011 & 80 & 0 & 80 & 206 \\
\hline 10 & Year 2010 & 96 & 1 & 95 & 263 \\
\hline 11 & Year 2009 & 106 & 4 & 102 & 261 \\
\hline 12 & Year 2008 & 100 & 2 & 98 & 255 \\
\hline 13 & Year 2007 & 82 & 1 & 81 & 174 \\
\hline 14 & Year 2006 & 90 & 1 & 89 & 235 \\
\hline 15 & Year 2005 & 53 & 1 & 52 & 121 \\
\hline 16 & Year 2004 & 41 & 1 & 40 & 76 \\
\hline 17 & Year 2003 & 50 & 3 & 47 & 96 \\
\hline 18 & Year 2002 & 30 & 1 & 29 & 57 \\
\hline 19 & Year 2001 & 39 & 2 & 37 & 89 \\
\hline 20 & Year 2000 & 28 & 0 & 28 & 46 \\
\hline Total & & 1721 & 35 & 1686 & 4311 \\
\hline
\end{tabular}


Table-2 and Figure-1 describe the importance of the subject change-management; this study reveals twelve languages used to wrote 1686 documents. These documents segregated into eleven categories with further explanations that the publications produced in;
Articles 820, Conference Papers, 533, Book Chapters 131, Review articles 92, Editorials 27, Notes 25, Books 20, Short Surveys 20, Letters 8, Conference Reviews 5, and Erratum 5.

Table-2: Utilization of languages in documents published on the subject change-management from 2000 - 2019

\begin{tabular}{|l|l|l|l|}
\hline S. No & Language & Documents & $\mathbf{\%}$ \\
\hline 1 & English & 1578 & $93.5 \%$ \\
\hline 2 & German & 58 & $3.4 \%$ \\
\hline 3 & French & 15 & $0.8 \%$ \\
\hline 4 & Chinese & 12 & $0.7 \%$ \\
\hline 5 & Spanish & 9 & $0.5 \%$ \\
\hline 6 & Portuguese & 3 & $0.1 \%$ \\
\hline 7 & Russian & 3 & $0.1 \%$ \\
\hline 8 & Croatian & 2 & $0.1 \%$ \\
\hline 9 & Italian & 2 & $0.1 \%$ \\
\hline 10 & Lithuanian & 2 & $0.1 \%$ \\
\hline 11 & Arabic & 1 & $0.06 \%$ \\
\hline 12 & Bosnian & 1 & $0.06 \%$ \\
\hline & & 1686 & \\
\hline
\end{tabular}

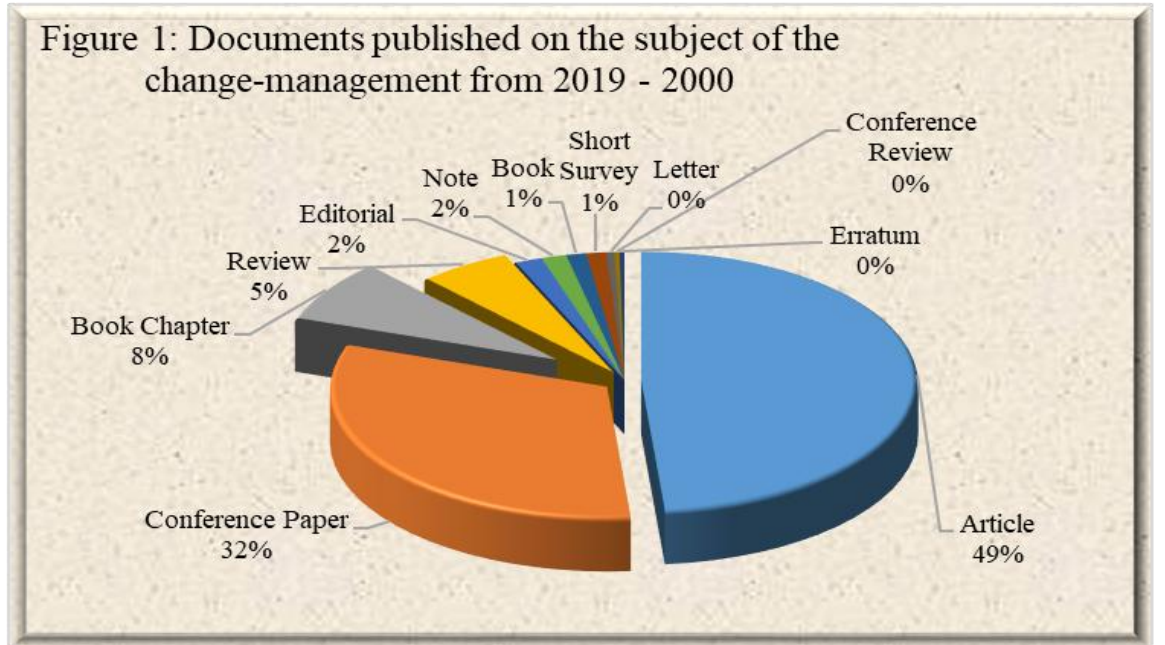

Fig-1: Documents published on the subject of the change-management from 2019-2000

We distributed data into seven categories of Dewey Decimal Classification (DDC). Figure-2 describes that; a) Business, Management and Accounting 422, b) Computer Science 378, c) Decision Sciences 164, d) Economics, Econometrics, and Finance 89, e) Engineering 302, f) Nursing 42, g) Psychology 36, and h) Social Sciences 293 produced documents from 2019 - 2000. The study picked five articles that got above 300 citations published in random years, i) Pearce. C.L. and Sims Jr. H.P [16]. Vertical versus shared leadership as predictors of the effectiveness of change management teams: An examination of the aversive, directive, transactional, transformational, and empowering leader behaviors 580, ii) Eick SG et al., [17]. Does code decay? Assessing the evidence from change management data 367, iii) Kumar V et al., [18]. Effect of communitybased behavior change management on neonatal mortality in Shivgarh, Uttar Pradesh, India: a clusterrandomized controlled trial 325, IV) Dunne, D., and Martin R [19]. Design thinking and how it will change management education: An interview and discussion 317, and V) Aladwani A.M [20]. Change management strategies for successful ERP implementation 312 citations. 


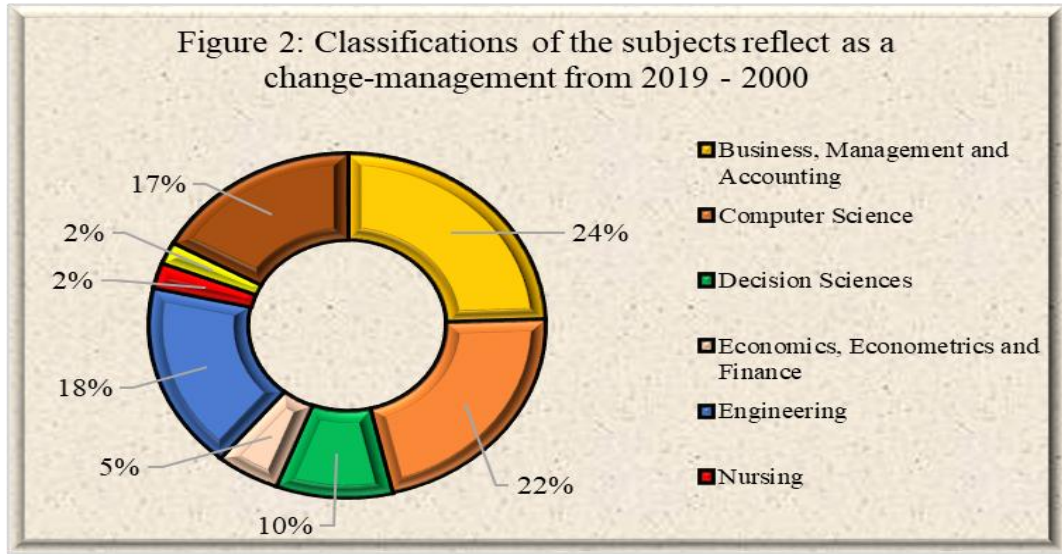

Fig-2: Classifications of the subjects as a change-management from 2019-2000

Figure-3 and Table-3 enlightens the authors' breakdown and contribution in writing the scripts of 1686 documents. Majority 1202; 71.2 documents written collaboratively, and $484 ; 29 \%$ by single or solo authors.

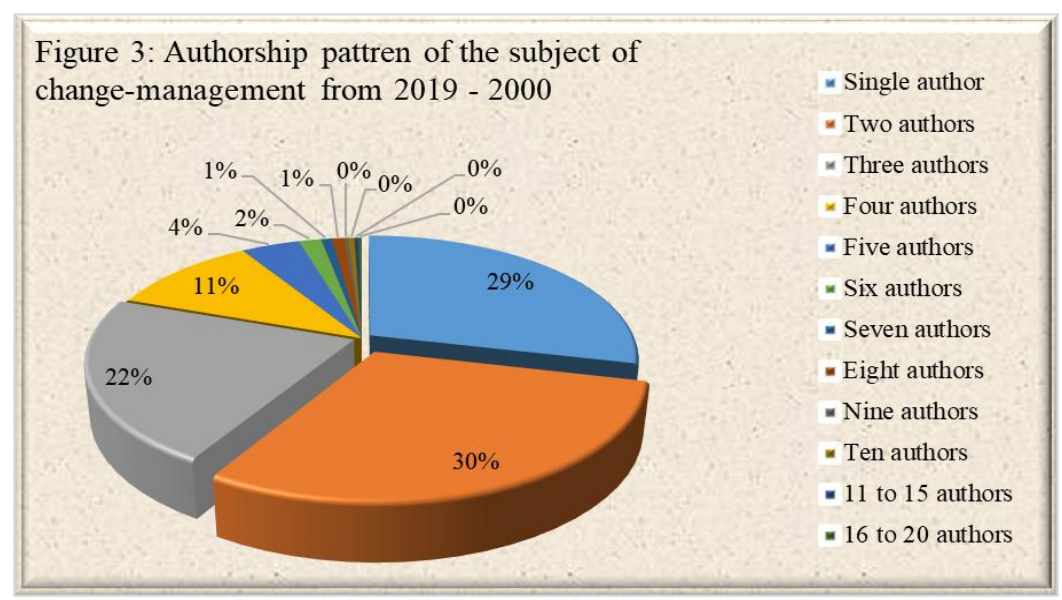

Fig-3: Authorship pattern of documents on the subject change-management from 2000 - 2019

Table-4: Authorship pattern of documents on the subject change-management from 2000 - 2019

\begin{tabular}{|c|c|c|c|c|c|c|c|c|c|c|c|c|c|c|c|c|c|c|c|c|c|c|}
\hline Authors & ิㅗㄱ & $\stackrel{\infty}{\bar{\pi}}$ & 굴 & ํํㄹ & กี่ & ت্ণ & $\stackrel{m}{\bar{\pi}}$ & בิำ & 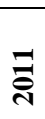 & 옥 & હેస్ & 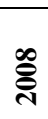 & હ્సે & ఫ్సి & હે̊̄ & હ્సે & 气ิં & 气ิ & ฮิ & ఫ్రి & हैं & 吾 \\
\hline Single author & 23 & 24 & 40 & 27 & 25 & $\begin{array}{l}3 \\
0\end{array}$ & 30 & 34 & 18 & $\begin{array}{l}2 \\
1\end{array}$ & 29 & $\begin{array}{l}2 \\
9\end{array}$ & $\begin{array}{l}3 \\
0\end{array}$ & $\begin{array}{l}2 \\
6\end{array}$ & $\begin{array}{l}1 \\
6 \\
\end{array}$ & $\begin{array}{l}2 \\
5\end{array}$ & $\begin{array}{l}1 \\
9\end{array}$ & $\begin{array}{l}1 \\
3\end{array}$ & $\begin{array}{l}1 \\
1\end{array}$ & $\begin{array}{l}1 \\
4\end{array}$ & 484 & 484 \\
\hline Two authors & 37 & 31 & 40 & 32 & 32 & $\begin{array}{l}2 \\
5\end{array}$ & 29 & 26 & 30 & $\begin{array}{l}3 \\
3\end{array}$ & 38 & $\begin{array}{l}3 \\
2\end{array}$ & $\begin{array}{l}2 \\
9\end{array}$ & $\begin{array}{l}2 \\
6\end{array}$ & $\begin{array}{l}1 \\
7\end{array}$ & 2 & $\begin{array}{l}1 \\
3\end{array}$ & 8 & $\begin{array}{l}1 \\
4\end{array}$ & $\begin{array}{l}1 \\
0\end{array}$ & 504 & $\begin{array}{l}100 \\
8\end{array}$ \\
\hline Three authors & 36 & 20 & 30 & 38 & 30 & $\begin{array}{l}1 \\
7\end{array}$ & 23 & 23 & 15 & $\begin{array}{l}2 \\
5\end{array}$ & 21 & $\begin{array}{l}1 \\
9\end{array}$ & $\begin{array}{l}1 \\
1\end{array}$ & $\begin{array}{l}1 \\
7\end{array}$ & $\begin{array}{l}1 \\
1\end{array}$ & 9 & $\begin{array}{l}1 \\
0\end{array}$ & 4 & 7 & 4 & 370 & $\begin{array}{l}111 \\
0\end{array}$ \\
\hline Four authors & 13 & 12 & 20 & 9 & 24 & 8 & 16 & 16 & 11 & 9 & 4 & 6 & 8 & 8 & 6 & 2 & 4 & 4 & 1 & & 181 & 724 \\
\hline Five authors & 5 & 4 & 8 & 5 & 4 & 6 & 7 & 5 & 1 & 3 & 3 & 7 & 1 & 7 & & 1 & 1 & & 3 & & 71 & 355 \\
\hline Six authors & 7 & 2 & 2 & 4 & & 1 & 3 & 1 & 3 & & 1 & 1 & & 2 & & & & & & & 27 & 162 \\
\hline $\begin{array}{l}\text { Seven } \\
\text { authors }\end{array}$ & & 3 & & & & & 2 & & & 1 & 1 & 2 & & 1 & 2 & 1 & & & & & 13 & 91 \\
\hline Eight authors & 4 & 1 & & & & 1 & 1 & 1 & 2 & 1 & 1 & & 2 & 1 & & & & & & & 15 & 120 \\
\hline Nine authors & 3 & & & & 1 & & & & & & 1 & & & & & & & & & & 5 & 45 \\
\hline Ten authors & 1 & & & 2 & & & & & & 1 & 1 & 1 & & & & & & & 1 & & 7 & 70 \\
\hline $\begin{array}{l}11 \text { to } 15 \\
\text { authors }\end{array}$ & 1 & 1 & & & & & & & & & 2 & & & 1 & & & & & & & 5 & 55 \\
\hline $\begin{array}{l}16 \text { to } 20 \\
\text { authors }\end{array}$ & & 1 & & & & & & 1 & & 1 & & 1 & & & & & & & & & 4 & 97 \\
\hline & $\begin{array}{l}13 \\
0\end{array}$ & 99 & $\begin{array}{l}14 \\
0\end{array}$ & $\begin{array}{l}11 \\
7\end{array}$ & $\begin{array}{l}11 \\
6\end{array}$ & $\begin{array}{l}8 \\
8\end{array}$ & $\begin{array}{l}11 \\
1\end{array}$ & $\begin{array}{l}10 \\
7\end{array}$ & 80 & $\begin{array}{l}9 \\
5\end{array}$ & $\begin{array}{l}10 \\
2\end{array}$ & $\begin{array}{l}9 \\
8\end{array}$ & $\begin{array}{l}8 \\
1\end{array}$ & $\begin{array}{l}8 \\
9\end{array}$ & $\begin{array}{l}5 \\
2\end{array}$ & $\begin{array}{l}4 \\
0\end{array}$ & $\begin{array}{l}4 \\
7\end{array}$ & $\begin{array}{l}2 \\
9\end{array}$ & $\begin{array}{l}3 \\
7\end{array}$ & $\begin{array}{l}2 \\
8\end{array}$ & $\begin{array}{l}168 \\
6\end{array}$ & $\begin{array}{l}432 \\
1\end{array}$ \\
\hline
\end{tabular}


Table-5 indicates that a total of 86 countries produced 1686 documents. Twenty countries participated in productivity by $1359 ; 56$ countries created $80.6 \%$ of documents, and the remaining 327 ; 19.3\%. Russian Federation and South Africa present 15 documents each. Austria, New Zealand, and Turkey 14 each. Saudi Arabia and South Korea 12 each. Denmark and Taiwan 11 each. Croatia, Latvia, and Singapore 9 each. Belgium, Indonesia, Japan, Norway, and Slovenia 8each. Czech Republic, Hungary, and Israel 7 each. Colombia, Greece, Ireland, and Morocco 6 each. Hong
Kong, Kuwait, and Thailand 5 each. Chile, Ghana, Portugal, and Slovakia 4 each. Argentina, Estonia, Jordan, Peru, Philippines, Serbia, and United Arab Emirates 3 each. Algeria, Cuba, Ethiopia, Lithuania, Luxembourg, Mexico, Sri Lanka, Tunisia, Uganda, and Ukraine 2 each. Azerbaijan, Bahrain, Bangladesh, Bosnia and Herzegovina, Botswana, Cyprus, Egypt, Fiji, Kenya, Lebanon, Macau, Nigeria, Oman, Qatar, Uruguay, Viet Nam, and Venezuela present one document each.

Table-5: Affiliation of countries in production of documents from largest to lowest

\begin{tabular}{|c|c|c|c|}
\hline S. No & Country name & Documents & $\%$ \\
\hline 1 & United States of America & 334 & $19.8 \%$ \\
\hline 2 & United Kingdome & 218 & $13 \%$ \\
\hline 3 & Germany & 156 & $9.2 \%$ \\
\hline 4 & Australia & 121 & $7.1 \%$ \\
\hline 5 & Canada & 93 & $5.5 \%$ \\
\hline 6 & India & 64 & $3.8 \%$ \\
\hline 7 & China & 63 & $3.7 \%$ \\
\hline 8 & France & 54 & $3.2 \%$ \\
\hline 9 & Italy & 39 & $2.3 \%$ \\
\hline 10 & Malaysia & 28 & $1.6 \%$ \\
\hline 11 & Netherland & 25 & $1.4 \%$ \\
\hline 12 & Pakistan & 24 & $1.4 \%$ \\
\hline 13 & Switzerland & 23 & $1.3 \%$ \\
\hline 14 & Romania & 22 & $1.3 \%$ \\
\hline 15 & Brazil & 21 & $1.2 \%$ \\
\hline 16 & Iran & 18 & $1.0 \%$ \\
\hline 17 & Finland & 17 & $1 \%$ \\
\hline 18 & Sweden & 16 & $1 \%$ \\
\hline 19 & Two countries present 15 documents & 30 & $1.7 \%$ \\
\hline 20 & Three countries 14 documents & 42 & $2.4 \%$ \\
\hline 21 & Poland & 13 & $0.7 \%$ \\
\hline 22 & Two countries present 12 documents & 24 & $1.4 \%$ \\
\hline 23 & Two countries present 11 documents & 22 & $1.3 \%$ \\
\hline 24 & Spain & 10 & $0.5 \%$ \\
\hline 25 & Three countries present 09 documents & 27 & $1.6 \%$ \\
\hline 26 & Not Clear & 8 & $0.4 \%$ \\
\hline 27 & Five countries present 08 documents & 40 & $2.3 \%$ \\
\hline 28 & Three countries present 07 documents & 21 & $1.2 \%$ \\
\hline 29 & Four countries present 06 documents & 24 & $1.4 \%$ \\
\hline 30 & Three countries present 05 documents & 15 & $0.8 \%$ \\
\hline 31 & Four countries present 04 documents & 16 & $1 \%$ \\
\hline 32 & Seven countries present 03 documents & 21 & $1.2 \%$ \\
\hline 33 & Ten countries present 02 documents & 20 & $1.1 \%$ \\
\hline 34 & Seventeen countries present 01 document & 17 & $1 \%$ \\
\hline & Total & \multicolumn{2}{|l|}{1686} \\
\hline
\end{tabular}

\section{DISCUSSION AND CONCLUSION}

The workplace is a dynamic word for workers; this place can motivate or demotivate, encourage, or discourage all ideas, actions, and plans created by an employee or business owner. Management started to change the worker's venue from one place to another for boosting the energy, efficiency, effectiveness, and performance of workers. Management of any organization adopted flexible strategies to get maximum benefits from minimum expenditures, the quantity of time, services, and tangible resources. In this study, we found that researchers' vast participation contributed and tried to cover-up all dimensions of the discipline of change management, a small component of business administration and management. 84.3 of documents published every year, and every 18 days of the calendar, one document wrote and came on an academic surface 
in these twenty-years of the studied period. Conference papers are the most effective tool to gauge audience responsiveness, and research articles get attraction inshape of citations from the people similar disciplines. The six classification areas of research cover every point of the subject change-management, because from the services sector to resource distribution changemanagement gated more importance in-facilitation of any project.

Disclaimer: None to declare.

Conflict of Interest: None to declare.

Funding Disclosure: None to declare

\section{REFERENCES}

1. Dukić, G., Dukić, D., \& Kozina, G. (2017). Change management in information institutions. Malaysian Journal of Library \& Information Science, 22(3), 53-68.

2. Callinan M. Change management: Sustainable Development via an Augmented EMS. InStrategic Sustainability 2017 Sep 8 (pp. 222-241). Routledge.

3. Hajri I, Göknil A, Briand L. A change management approach in product lines for use case-driven development and testing. In23rd International Working Conference on Requirements Engineering: Foundation for software Quality (REFSQ 2017) 2017.

4. AlSanad A, Chikh A. Software requirements change management-A comprehensive model. InWorld Conference on Information Systems and Technologies 2017 Apr 11 (pp. 821-830). Springer, Cham.

5. Alqahtani AA, Alenezi MM, Alhajeri SS. Change management in Kuwait public schools: A mixedmethods study. Psychology and Education, 2017; 54(1-2), 1-12.

6. Al-Ali AA, Singh SK, Al-Nahyan M, Sohal AS. Change management through leadership: the mediating role of organizational culture. International Journal of Organizational Analysis. 2017 Sep 4.

7. Giussi MV, Baum A, Plazzotta F, Muguerza P. Change Management Strategies: Transforming a Difficult Implementation into a Successful One. Studies in health technology and informatics. 2017 Jan 1;245:813-7.

8. Yeole A, Kalbande DR. Change Management Approach for Integrating IoT Technology in Healthcare System. In2018 International Conference on Smart City and Emerging Technology (ICSCET) 2018 Jan 5 (pp. 1-4). IEEE.
9. Sulistiyani E, Susanto TD. Change Management Methodology for e-Government Project in Developing Countries: A Conceptual Model. In2018 Third International Conference on Informatics and Computing (ICIC) 2018 Oct 17 (pp. 1-5). IEEE.

10. Gupta S. Impact of change management: A case study of select Indian manufacturing organizations. Prabandhan: Indian Journal of Management, 2018; 11(10), 39-52.

11. Bonanomi MM. Application of the Methodology for Change Management: The Case of a Canadian Multidisciplinary Design Firm. Springer Briefs in Applied Sciences and Technology, 2019; 65-75.

12. Potdar A, Unnikrishnan S, Singh A. A framework for climate change management in organisations: a case for India. World Review of Entrepreneurship, Management and Sustainable Development. 2019;15(3):303-34.

13. Nuraliati A, Azwari PC, Yadiati W. The effect of change management on the quality of management accounting information. Opcion, 2019; 35(20),945-960.

14. Kristensen NS, Andreasen LB, Kofoed LB, BruunPedersen JR. Balancing a change management process: A case study of how to approach curriculum change in higher education. InSEFI annual conference 2019European Society for Engineering Education. Annual Conference proceedings 2019 (pp. 1926-1936). SEFI: European Association for Engineering Education.

15. Kho J, Gillespie N, Martin-Khan M. A systematic scoping review of change management practices used for telemedicine service implementations. BMC health services research. 2020 Dec;20(1):16.

16. Pearce CL, Sims Jr HP. Vertical versus shared leadership as predictors of the effectiveness of change management teams: An examination of aversive, directive, transactional, transformational, and empowering leader behaviors. Group dynamics: Theory, research, and practice. 2002 Jun;6(2):172.

17. Eick SG, Graves TL, Karr AF, Marron JS, Mockus A. Does code decay? assessing the evidence from change management data. IEEE Transactions on Software Engineering. 2001 Jan;27(1):1-2.

18. Gupta R, Kumar A. Molecular imprinting in sol? gel matrix. Biotechnology Advances. 2008 Jan 1;26(6):533-47.

19. Dunne D, Martin R. Design thinking and how it will change management education: An interview and discussion. Academy of Management Learning \& Education. 2006 Dec 1;5(4):512-23.

20. Aladwani AM. Change management strategies for successful ERP implementation. Business Process management journal. 2001 Aug 1. 